\title{
Impact of kinesin Eg5 inhibition by 3,4-dihydropyrimidin-2(1H)-one derivatives on various breast cancer cell features
}

\author{
Bruna C Guido ${ }^{1}$, Luciana M Ramos², Diego O Nolasco ${ }^{3,4}$, Catharine C Nobrega ${ }^{1}$, Bárbara YG Andrade ${ }^{1}$,
} Aline Pic-Taylor ${ }^{5}$, Brenno AD Neto ${ }^{2}$ and José R Corrêa ${ }^{1 *}$

\begin{abstract}
Background: Breast cancer is a complex heterogeneous disease and is one of the leading causes of death among women. In addressing the need for treatments of this life-threatening illness, we studied 3,4-dihydropyrimidin-2 $(1 \mathrm{H})$-one (or thione) derivatives (DHPMs), a class of inhibitor molecules of the Eg5 motor spindle protein that shows pronounced antitumor activity against several cancer cell lines.

Methods: An in vitro screening was performed for identification of DHPMs with potent antitumor effects on MCF-7 and MDA-MB-231 cells and the selected DHPMs were evaluated for their inhibitory activity on Eg5 both in silico, using Molecular dynamics, and in vitro Eg5 inhibition assays. Analysis of cell death induction, proliferation, cell cycle and cancer stem cells (CSC) profile were performed by flow cytometry to assess the influence of the selected DPHMs on these important tumor features. Finally, the effects of DHPM treatment on tube formation were evaluated in vitro using HUVEC cells, and in vivo using a model on chorioallantoic membrane (CAM) of fertilized eggs.

Results: We identified five DHPMs with pronounced inhibitory activity on Eg5 motor protein interfering with the proper mitotic spindle assembly during cell division. These compounds impair the correct conclusion of cell cycle of the breast cancer cells and showed to be selective for tumor cells. Moreover, DHPMs modulate the CD44 $/$ CD24- phenotype leading to a decrease in the CSC population in MDA-MB-231 cells, an important effect since CSC are resistant to many conventional cancer therapies and play a pivotal role in tumor initiation and maintenance. This observation was confirmed by the results which demonstrated that DHPM treated cells had impaired proliferation and were unable to sustain angiogenesis events. Finally, the DHMP treated cells were induced to apoptosis, which is one of the most pursued goals in drug development.
\end{abstract}

Conclusions: The results of our study strongly suggest that DHPMs inhibit important tumorigenic features of breast cancer cells leading them to death by apoptosis. These findings firmly point to DHPM molecular architecture as a promising alternative against breast cancer.

Keywords: 3,4-dihydropyrimidin-2(1H)-one (or thione), Breast cancer, Kinesin Eg5, Angiogenesis inhibitors, Cancer stem cells

\footnotetext{
*Correspondence: correa@unb.br

'Department of Cell Biology, Laboratory of Electron Microscopy, University of Brasília (IB-UnB), Campus Universitário Darcy Ribeiro, Brasília, DF, Brazil

Full list of author information is available at the end of the article
} 


\section{Background}

Breast cancer remains the most common malignancy among women and the leading cause of death, accounting for $14 \%$ of the total estimated deaths attributed to cancer in women $[1,2]$. In order to face this life-threatening illness, the search for new molecules capable of targeting mitosis without disrupting microtubule dynamics has significantly increased to be applied in new antineoplastic therapies [3-5]. A promising alternative to eliminate cancer cell mitotic progression relies on interference in the function of some essential mitosis molecules such as microtubule-associated proteins, particularly spindle motor proteins [6,7].

Kinesin Eg5 is one fundamental spindle motor protein and its specific role during mitosis in the assembly and maintenance of the bipolar spindle has rendered it an attractive therapeutic target that could prevent cell cycle progression through mitosis and promote tumor growth regression [8-10]. Inhibition of Kinesin Eg5 stops centrosome migration to the polar region resulting in a monoastral spindle formation [11,12], and this abnormal phenotype plays a critical role in activation of the mitotic spindle assembly checkpoint (SAC). The SAC promotes mitotic arrest at metaphase/anaphase transition through the maintenance of cdc2/cyclin B activity $[8,11,13]$.

In addition to proliferative events that maintain tumor development, some cancer cells also have the ability to invade and colonize restricted areas belonging to other tissue types essentially through a process observed in malignant tumors named metastasis [14]. Invasion and metastasis are landmark angiogenesis-dependent events that transform a locally growing tumor into a systemic, metastatic and severe life-threatening disease [15,16].

Cancer Stem Cells (CSC), also known as initiating cancer cells, play a key role in the emergence of typical neoplastic hallmarks. These cells are able to dictate invasion, metastasis, heterogeneity, and therapeutic resistance in tumors $[17,18]$. Furthermore, CSC are capable of selfrenewal and differentiation, and as such play a pivotal role in tumor initiation and maintenance together with spreading cancer cells to regional lymph nodes and later to other tissues and organs [19].

Resistance of putative CSC against many conventional cancer therapies is associated with two main characteristics: 1) a slow cell division rate; and 2) the ability to efflux antitumor drugs [20]. Furthermore, CSC undertake an important role in the relapse of patients post-treatment and could therefore be responsible for the incurable nature of many advanced solid tumors including metastatic breast cancer [21]. The aforementioned CSC features make these cells potential targets for cancer treatment by specific compounds that act by modulating mesenchymalepithelial transition.

In recent years, compounds that specifically inhibit Eg5 function have been identified, such as 3,4-
dihydropyrimidin-2(1H)-one (or thione) (DHPMs) [22-24]. These molecules comprise a class of heterocyclic compounds obtained through Biginelli reaction that has monastrol as their prototype [25]. The Eg5 inhibition by DHPMs is considered an attractive approach to cancer treatment since mitotic kinesins are exclusively involved in the formation and function of the mitotic spindle, and some of them are only expressed in proliferating cells [26]. The Eg5 inhibitors therefore not interfere with other microtubuledependent processes $[27,28]$, which are the main reason for the neurotoxicity of anti-microtubule agents [29]. It was shown that monastrol has antitumor activity against diverse cancer cell types such as renal, breast and glioma cell lines [24,30].

Here, we provide the results of a study based on the activity of thirty-seven DHPM derivatives, recently described [31] by our group, on breast cancer cells. In addition, we identified and functionally characterized the compounds that provide potent DHPM-dependent Kinesin Eg5 inhibition, and were capable of impairing metaphase/anaphase transition together with cell proliferation. Moreover, the DHPMs induce CSC differentiation into epithelial phenotype, which can controls essential properties to establishment, progression and recrudescence of tumors. Finally, the DHPM derivatives were also capable of successfully inducing cancer cells to death by apoptosis.

\section{Methods}

\section{Materials and equipment}

A detailed description is available in Additional file 1.

\section{Cells and cell culture}

MCF-7 and MDA-MB-231 cell lines were used as model of breast cancer cells in this work. Our choice was based mainly on the fact that breast cancer is the most prevalent type of cancer in women worldwide and also because of the differences on metastasis capability and cancer stem cells population in these cell lines. These features affect the cell cycle and mitosis rate, which are directed linked with the predicted DHPMs effect.

MCF-7 cell line and primary culture of connective tissue cells were provided by the Laboratory of Morphology, University of Brasília (Brasília, BR). MDA-MB-231 cells were purchased from Rio de Janeiro Cell Bank (RJCB - Rio de Janeiro, BR). Cell line characterization and authentication was conducted by RJCB using short tandem repeat profiling. Primary culture cells were taken from healthy human dental pulp predominantly consisting of fibroblasts and were used as normal control cells. MCF-7 cells and fibroblasts were grown in complete DMEM and maintained at $37^{\circ} \mathrm{C}$ with $5 \% \mathrm{CO}_{2}$. MDAMB-231 cells were grown in Leibovitz L15 medium at 
$37^{\circ} \mathrm{C}$ without $\mathrm{CO}_{2}$. Culture media were supplemented with $10 \%$ fetal bovine serum and $25 \mu \mathrm{g} / \mathrm{mL}$ of gentamicin.

\section{Catalytic synthesis of the 3,4-dihydropyrimidin-2(1H)-one (or thione) derivatives (DHPMs)}

The thirty-seven compounds tested in this work (Table 1) were provided by the Laboratory of Medicinal and Technological Chemistry, University of Brasília, and synthesized by the catalytic Biginelli reaction as previously described [31].

\section{Cell viability assays}

Fibroblasts, MCF-7 (both $3 \times 10^{3} /$ well) and MDA-MB$231\left(5 \times 10^{3} /\right.$ well $)$ cells were plated in 96 -well plates and treated with DHPMs for 24, 48 and $72 \mathrm{~h}$. Cytotoxicity was determined using 3-(4,5-dimethylthiazol-2-yl)-2,5diphenylterazolium bromide (MTT) according to the manufacturer's instructions. Absorbance readings were measured by a spectrophotometer. Cell viability was normalized to control (vehicle only).

\section{Molecular dynamics}

Molecular dynamics simulations (MD) of the Eg5 protein and Eg5 protein complexes with each of the five tested compounds were conducted in an aqueous environment, using the Single Point Charge - SPC - water model [32]. Analyses were performed using the GROMACS 4 computer package [33]. The dynamics utilized the 3-D protein model, collected from PDB (PDB-ID $1 \mathrm{X} 88)$, as the initial structure. The ensembles were immersed in approximately 65,600 water molecules in dodecahedral boxes with a minimum distance of $0.7 \mathrm{~nm}$ between complex-box frontiers. Sodium ions were also inserted in the ensembles in order to neutralize system charges. (See details in the Additional file 1).

\section{Kinesin inhibition assay}

Kinesin inhibition assays were performed using Kinesin ELIPA (Enzyme Linked Inorganic Phosphate Assay). Reactions were conducted in 96-well plates according to the manufacturer's recommendations (Kinesin ELIPA Biochem Kit - BK060). The half maximal inhibitory concentration of each compound was added to the reactions (4 m - 197.3 $\mu \mathrm{M}$; 4bt (known as dimethylenastron) $126.9 \mu \mathrm{M} ; 4 \mathrm{p}-87.54 \mu \mathrm{M} ; 4 \mathrm{bc}-234.9 \mu \mathrm{M} ; 4 \mathrm{x}-276.5 \mu \mathrm{M}$ and monastrol $-110.4 \mu \mathrm{M}$ ) with readings taken at 30 second intervals for 30 minutes at room temperature using a spectrophotometer at $360 \mathrm{~nm}$.

\section{a-tubulin immunostaining}

Aliquots of $7 \times 10^{4}$ MCF-7 cells were seeded onto $12 \mathrm{~mm}$ round glass coverslips placed in the base of each well of a 24-well plate. After adhesion, cells were treated for 24 and $48 \mathrm{~h}$ with the pre-selected compounds at their maximum non-cytotoxic concentrations to normal cells or incubated with culture medium only for the same duration (negative control). Cells were washed with PBS, fixed with $3.7 \%$ formaldehyde, permeabilized with $0.1 \%$ Triton X-100 and blocked in PBS supplemented with $1 \%$ skimmed milk, $2.5 \%$ bovine serum albumin (BSA) and $8 \%$ fetal bovine serum (FBS) at room temperature. Cells were incubated overnight with mouse anti- $\alpha$-tubulin antibody $(1: 500)$ at $4^{\circ} \mathrm{C}$, followed by incubation with a secondary antibody: Alexa Fluor 488 rabbit anti-mouse IgG (1:400), for 1 hour at $37^{\circ} \mathrm{C}$. Nuclei were stained with $300 \mathrm{nM}$ DAPI. The coverslips were mounted with ProLong Gold Antifade and specimens observed under a laser scanning confocal microscope.

\section{Transmission electron microscopy analysis}

Aliquots of $8 \times 10^{5}$ MCF-7 cells were seeded in 12-well plates and ultra-structural analysis performed on controls or after $48 \mathrm{~h}$ of treatment with $4 \mathrm{p}(0.4 \mathrm{mM})$. Cells were washed twice with PBS and fixed overnight with glutaraldehyde $(2.5 \%)$ at $4{ }^{\circ} \mathrm{C}$. Cells were subsequently washed with $0.1 \mathrm{M}$ sodium cacodylate buffer $(\mathrm{pH} 7.2)$ and post-fixed in $1 \%$ osmium tetroxide and $0.8 \%$ potassium ferricyanide $\left(10 \mathrm{mM} \mathrm{CaCl}_{2}\right.$ in $0.2 \mathrm{M}$ sodium cacodylate buffer). Samples were washed twice with $0.1 \mathrm{M}$ sodium cacodylate buffer ( $\mathrm{pH}$ 7.2) and in-block staining was performed for $16 \mathrm{~h}$ with $0.5 \%$ uranyl acetate at $4^{\circ} \mathrm{C}$. Cells were dehydrated in a graded acetone series (50$100 \%$ ) and embedded in Spurr resin. Ultrathin sections were observed in a $\mathrm{Jeol}^{\circ} 1011$ transmission electron microscope (TEM) at $80 \mathrm{kV}$.

\section{Flow cytometry analysis}

MCF-7 and MDA-MB-231 cells were seeded $\left(1 \times 10^{5}\right)$ in 12-well plates and treated with the five pre-selected DHPMs for the determined time for each experiment. Treatment for apoptosis assay, cancer stem cell, and cell cycle analysis was conducted using $4 \mathrm{~m}(1 \mathrm{mM})$, $4 \mathrm{bt}$ (dimethylenastron, $0.8 \mathrm{mM}), 4 \mathrm{p}(0.4 \mathrm{mM}), 4 \mathrm{bc}(1.0 \mathrm{mM})$, $4 \mathrm{x}(0.8 \mathrm{mM})$ and monastrol (positive control, $1.0 \mathrm{mM})$. For proliferation assays, cells were treated with $\mathrm{IC}_{50}$ concentrations of each compound. Adherent and floating cells were harvested at the same tube and pelleted by centrifugation at $300 \mathrm{~g}$ for 5 minutes and stained. Data acquisition of these two fractions put together was performed on a FACSCalibur flow cytometer using CellQuest software and analysed using the FloJo Software.

\section{Apoptosis and necrosis assay}

Untreated control cells and DHPMs-treated for $72 \mathrm{~h}$ cell samples were stained with Annexin-V-FITC or Annexin-VAlexa Fluor 680 and propidium iodide according to the manufacturer's instructions. 
Table 1 Synthesized DHPM derivatives

\begin{tabular}{|c|c|c|c|c|c|c|}
\hline \multirow[t]{2}{*}{ Ent } & \multicolumn{4}{|l|}{ Reagent } & \multirow[t]{2}{*}{ Prod. } & \multirow[t]{2}{*}{ Yield (\%) } \\
\hline & $\mathrm{R}^{1}$ & $\mathrm{R}^{2}$ & $\mathrm{R}^{3}$ & $x$ & & \\
\hline 1 & $\mathrm{Ph}$ & Me & Me & $\mathrm{O}$ & $4 c$ & 99 \\
\hline 2 & $\mathrm{Ph}$ & $\mathrm{OCH}_{2} \mathrm{CH}_{3}$ & Me & $S$ & $4 d$ & 93 \\
\hline 3 & $\mathrm{Ph}$ & Me & Me & S & $4 e$ & 83 \\
\hline 4 & 4-Cl-Ph & $\mathrm{OCH}_{2} \mathrm{CH}_{3}$ & Me & $\mathrm{O}$ & $4 f$ & 87 \\
\hline 5 & 4-Cl-Ph & $\mathrm{OCH}_{2} \mathrm{CH}_{3}$ & Me & $S$ & $4 h$ & 80 \\
\hline 6 & 4-Cl-Ph & Me & Me & S & $4 i$ & 77 \\
\hline 7 & 3-OH-Ph & $\mathrm{OCH}_{2} \mathrm{CH}_{3}$ & Me & $\mathrm{O}$ & $4 j$ & 98 \\
\hline 8 & 3-OH-Ph & $\mathrm{Me}$ & Me & $\mathrm{O}$ & $4 k$ & 80 \\
\hline $9^{a}$ & 3-OH-Ph & $\mathrm{OCH}_{2} \mathrm{CH}_{3}$ & Me & S & Mon & 93 \\
\hline 10 & 3-OH-Ph & Me & Me & $S$ & $4 m$ & 88 \\
\hline 11 & 2-OH-Ph & $\mathrm{OCH}_{2} \mathrm{CH}_{3}$ & Me & $\mathrm{O}$ & $4 n$ & 84 \\
\hline 12 & 2-OH-Ph & Me & Me & $\mathrm{O}$ & 40 & 80 \\
\hline 13 & 2-OH-Ph & $\mathrm{OCH}_{2} \mathrm{CH}_{3}$ & Me & $S$ & $4 p$ & 84 \\
\hline 14 & 2-OH-Ph & Me & Me & $S$ & $4 q$ & 90 \\
\hline 15 & $3-\mathrm{NO}_{2}-\mathrm{Ph}$ & $\mathrm{OCH}_{2} \mathrm{CH}_{3}$ & Me & $\mathrm{O}$ & $4 r$ & 96 \\
\hline 16 & $3-\mathrm{NO}_{2}-\mathrm{Ph}$ & $\mathrm{OCH}_{2} \mathrm{CH}_{3}$ & Me & S & $4 t$ & 86 \\
\hline 17 & $3-\mathrm{NO}_{2}-\mathrm{Ph}$ & Me & Me & $S$ & $4 u$ & 86 \\
\hline 18 & $2-\mathrm{NO}_{2}-\mathrm{Ph}$ & $\mathrm{OCH}_{2} \mathrm{CH}_{3}$ & Me & $\mathrm{O}$ & $4 v$ & 70 \\
\hline 19 & $2-\mathrm{NO}_{2}-\mathrm{Ph}$ & Me & Me & $\mathrm{O}$ & $4 x$ & 60 \\
\hline 20 & $2-\mathrm{NO}_{2}-\mathrm{Ph}$ & Me & Me & S & $4 z$ & $60^{e}$ \\
\hline 21 & 4-OH-3-MeO-Ph & $\mathrm{OCH}_{2} \mathrm{CH}_{3}$ & Me & $\mathrm{O}$ & $4 \mathrm{ba}$ & 98 \\
\hline 22 & 4-OH-3-MeO-Ph & $\mathrm{OCH}_{2} \mathrm{CH}_{3}$ & Me & S & $4 b c$ & 85 \\
\hline 23 & 4-OH-3-MeO-Ph & Me & Me & S & $4 \mathrm{bd}$ & 85 \\
\hline 24 & $\mathrm{H}$ & $\mathrm{OCH}_{2} \mathrm{CH}_{3}$ & Me & $\mathrm{O}$ & 4be & 96 \\
\hline 25 & Me & $\mathrm{Me}$ & Me & $\mathrm{O}$ & $4 b j$ & 66 \\
\hline 26 & Me & $\mathrm{OCH}_{2} \mathrm{CH}_{3}$ & Me & S & $4 b k$ & 70 \\
\hline 27 & & $\mathrm{OCH}_{2} \mathrm{CH}_{3}$ & Me & $\mathrm{O}$ & $4 \mathrm{bm}$ & 87 \\
\hline 28 & & Me & Me & $\mathrm{O}$ & $4 b n$ & 79 \\
\hline $29^{b}$ & & $\mathrm{OCH}_{2} \mathrm{CH}_{3}$ & Me & S & 4bo & 70 \\
\hline 30 & & Me & Me & S & $4 b p$ & 71 \\
\hline 31 & 3-OH-Ph & & & $\mathrm{O}$ & $4 b q$ & 60 \\
\hline $32^{c}$ & 3-OH-Ph & & & S & $4 \mathrm{br}$ & 72 \\
\hline 33 & 3-OH-Ph & & & 0 & $4 \mathrm{bs}$ & 70 \\
\hline
\end{tabular}

Table 1 Synthesized DHPM derivatives (Continued)

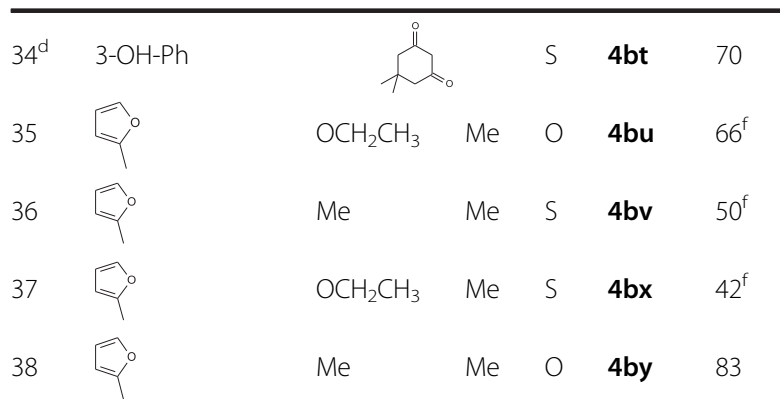

${ }^{\mathrm{a}}$ Monastrol. ${ }^{\mathrm{b}}$ Piperastrol. ${ }^{\mathrm{c}}$ Enastron. ${ }^{\mathrm{d}}$ Dimethylenastron. ${ }^{\mathrm{e}} 12 \mathrm{~h}$ of reaction. fProduct formation was above $90 \%$, but there was considerable loss during purification column chromatography.

37 DHPM derivatives and monastrol were studied in this work.

\section{$C D 44^{+} / C D 24^{-}$expression analysis}

Expression level of CD44 and CD24 in treated and control MCF-7 or MDA-MB-231 cells was measured after $24 \mathrm{~h}$ of treatment. Cells were washed in PBS with $1 \%$ BSA. Antibodies against CD44-FITC and CD24-PE were added at the dilution suggested by the manufacturer in $\mathrm{PBS} / 1 \% \mathrm{BSA}$ and incubated on ice for 30 minutes.

\section{Proliferation assay}

MCF-7 and MDA-MB-231 cells were labeled with 5(and 6-)-carboxyfluorescein diacetate succinimidyl ester (CFSE) prior to culture. After adhesion, cells were treated with DHPMs or maintained in culture medium only (control) for $72 \mathrm{~h}$. The percentage of proliferative cells was calculated based on the CFSE fluorescence profile analysis of the tested samples compared to that of the fixed undivided control cells (treated with $10 \mu \mathrm{M}$ of colchicine) using the FlowJo software.

\section{Cell cycle analysis}

Control and DHPM-treated cells were harvested at 24, 48 and $72 \mathrm{~h}$, resuspended in ice-cold PBS and fixed with $70 \%$ ethanol on ice. Cells were then washed with PBS, harvested and incubated with propidium iodide solution (0.1\% Triton X-100, $10 \mu \mathrm{g} / \mathrm{mL}$ propidium iodide, $100 \mu \mathrm{g} / \mathrm{mL}$ DNase free RNase) for $10 \mathrm{~min}$ at $37^{\circ} \mathrm{C}$. For analysis of cell populations in each cell cycle phase, the sub-G1 picks were excluded and the plots were generated by cell cycle platform data analysis by the FlowJo Software.

\section{HUVEC tube formation assay}

The anti-angiogenic potential of DHPMs was tested using an in vitro Angiogenesis Assay Kit according to the manufacturer's instructions. Aliquots of $8 \times 10^{3}$ HUVEC cells were resuspended in medium supplemented with endothelial cell growth supplement (1 DMEM:1 RPMI, 2\% SFB, $25 \mu \mathrm{g} / \mathrm{ml}$ gentamicin, $15 \mu \mathrm{g} / \mathrm{ml}$ ECGS) with or without $30 \mu \mathrm{M}, \mathrm{IC}_{50}$ or $300 \mu \mathrm{M}$ of DHPM treatment and were 
seeded onto the surface of the polymerized ECMatrix ${ }^{\mathrm{Tw}}$ in 96-well plates. These plates were incubated for 11 hours at $37^{\circ} \mathrm{C}$, in $5 \% \mathrm{CO}_{2}$. Wells were subsequently photographed using an inverted light microscope at 20x magnification and tube formation analyzed. Seven fields per group of 3 independent experiments were quantified by pattern recognition according to manufacturer's instructions.

\section{Chorioallantoic membrane (CAM) assay}

DHPM anti-angiogenic potential was also tested in vivo using a CAM assay performed according to Ribatti, [34] with some experimental time adaptations according to Sun et al. [35]. A minimum of 3 fertilized eggs was used per group. On the 10th day, $1 \times 10^{5}$ MCF-7 or MDA-MB-231 cells resuspended in supplemented culture medium (experimental control) or in medium supplemented with $500 \mathrm{ng}$ of compounds $4 \mathrm{~m}$, 4bt (dimethylenastron), 4p, 4bc, 4x, monastrol and genistein (as the anti-angiogenic control) were implanted into a chorioallantoic membrane (CAM) in a $2 \mathrm{~mm}^{2}$ hydrolysate collagen hemostatic sponge. Blood vessels were quantified on the 17th day by Wimasis Image Analysis. All blood vessels emerging from the grafts were included in the quantification.

\section{Statistical analysis}

The quantitative results are presented as the mean \pm SEM for at least three repeated individual experiments for each group. Statistical analyses were performed using GraphPad Prism 5 Software. Statistical significance of differences was determined by ANOVA with post-hoc comparison by the Bonferroni test. A P value of $<0.05$ was considered statistically significant.

\section{Results}

DHPM derivatives produce a dose and time dependent cytotoxicity and are selective for tumor cells

Monastrol (a DHPM derivative) was the first known small cell-permeable molecule with potential inhibitory properties against the mitotic machinery [11]. Our work is based on compounds with the same monastrol scaffold, that are, 37 newly synthesized 3, 4-dihydropyrimi$\operatorname{din}-2(1 \mathrm{H})$-one (or thione) derivatives (see structures in Table 1). Preview screen tests were conducted in order to identify high antitumor activity against human breast tumor cells together with fewer side effects on normal cells. After $72 \mathrm{~h}$ of treatment, 10 of 37 compounds induced $\geq 60 \%$ of MCF-7 cells to death and 30 demonstrated the same activity on MDA-MB-231 cells (Additional file 2: Figure S1). Five of the DHPMs: $4 \mathrm{~m}$, 4bt (dimethylenastron), 4p, 4bc and 4x showed the highest activities leading to a significant decrease in cell viability in both cell lines at all concentrations tested $(100 \mu \mathrm{M}-1.00 \mathrm{mM})$ (Figure 1A).
To establish the optimal treatment concentration for each one of these five compounds, a cell viability assay with human fibroblasts (normal cells) was conducted using concentrations that induce at least $70 \%$ of death in breast tumor cells in both cell lines at $72 \mathrm{~h}$ of treatment. The highest concentration of each derivative that did not show any significant cytotoxic effects on normal cells (maximum non-cytotoxic concentration to normal cells) was selected to conduct further experiments (Figure 1B and Table 2). This experiment shows that with exception of the $4 \mathrm{p}$, compounds have selectivity for tumor cells as they are in general, dose-dependent for tumor cells, but not for normal cells.

The half maximal inhibitory concentration $\left(\mathrm{IC}_{50}\right)$ was calculated based on the treatment of tumor cells for $72 \mathrm{~h}$ (Table 2). The $\mathrm{IC}_{50}$ values obtained from MDA-MB231 cells treated with $4 \mathrm{~m}$, 4bt (dimethylenastron) and $4 \mathrm{p}$ derivatives were smaller than those achieved from monastrol. Although $4 \mathrm{bc}$ and $4 \mathrm{x}$ show higher concentrations associated to $\mathrm{IC}_{50}$, their activities are not dose dependent for normal cells as they were for tumor cells (Figure 1B). Finally, the observed activity of these five selected molecules shows time-dependent effects with the best time for treatment defined as $72 \mathrm{~h}$ (Figure $1 \mathrm{C}$ ).

\section{DHPMs induce severe morphological alterations in breast tumor cells}

The five selected derivatives produced significant morphological alterations to MDA-MB-231 cells after $72 \mathrm{~h}$ of treatment (Figure 2). Only the 4bt (dimethylenastron), $4 \mathrm{p}$ and $4 \mathrm{bc}$ derivatives produced the same results with MCF-7 cells under the same treatment conditions (Figure 2). These changes were characterized by a reduction in cell size, absence of focal adhesion points, rounded morphology and minor cell detachment from the surface where they had been seeded. A significant reduction of cell number on the cover slips from treated groups in comparison to the control group was also observed. This feature suggests that many cells died as a result of the actions of the derivatives used (Figure 2). The $4 \mathrm{~m}$ and $4 \mathrm{x}$ derivatives caused no significant alterations to MCF-7 cells, similar to the observed with untreated control samples (Figure 2).

\section{DHPMs influence kinesin Eg5 movements in different ways}

Molecular dynamics assays were performed in order to verify the binding pattern and influence of the five DHPMs on Eg5 behavior. It is believed that the protein's movements exert important influence over its activity [36]. Thus, the in silico study of induced protein stiffening, together with the in vitro data, may provide an interesting overview of the link between derivative impact on protein movements and its inhibitory activity.

The different binding patterns observed for the DHPM derivatives tested (Figure 3) show that the interaction 


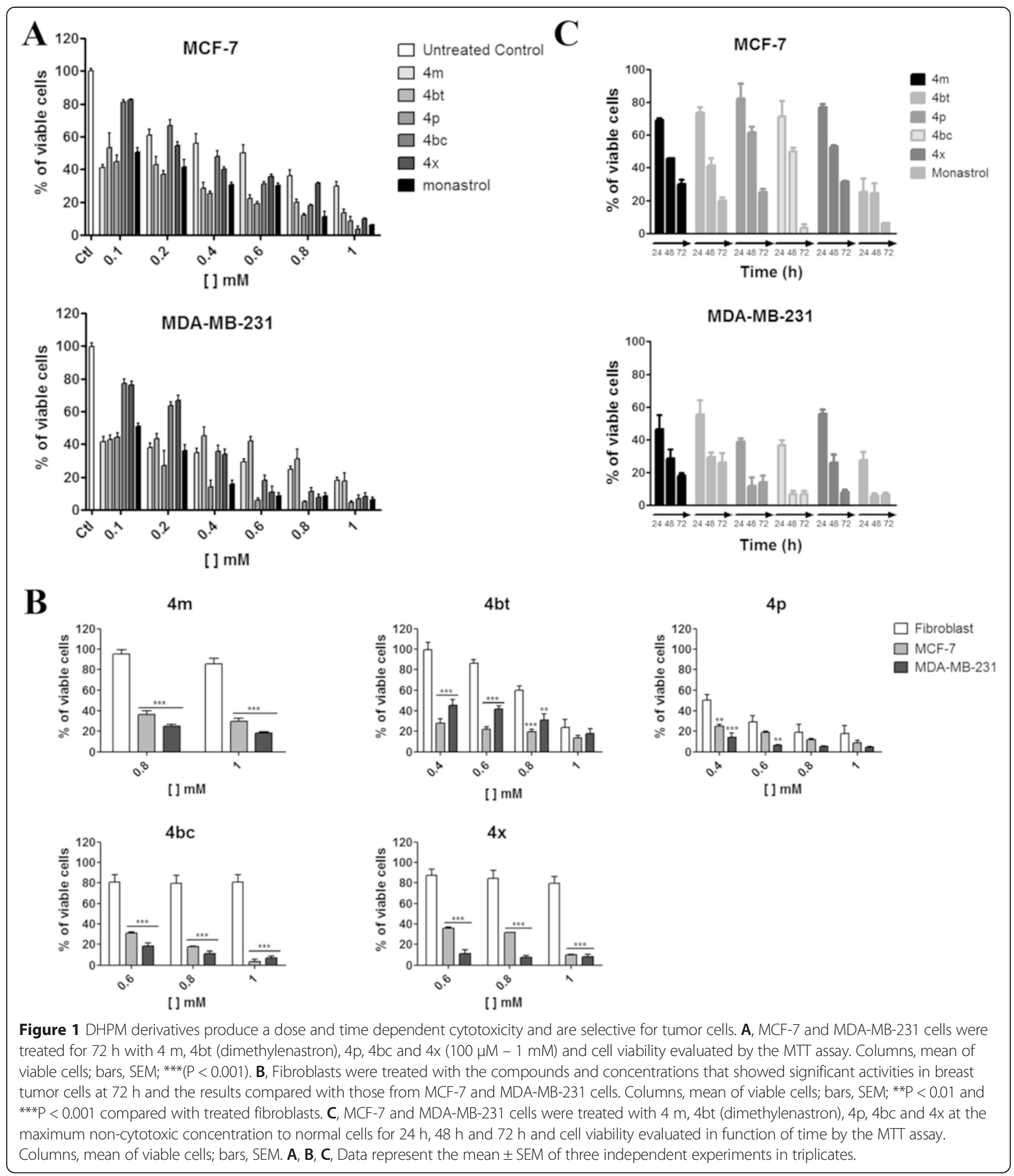

between some Eg5 residues and the DHPM derivative is highly significant. This is exemplified by the $4 \mathrm{bc}$ derivative, which interacts directly with Leu214 and Arg119, and also has two water-mediated interactions with Glu116, strongly tying the ligand-binding site (Figure 3 ). It is important to note that $4 \mathrm{bc}$ derivative interacts with
Arg119, in a similar way to monastrol, but instead of interacting with Glu118, it bonds to Glu116, which ensures stability of the $\alpha$-helix. The interaction with Leu214 is also noticeable as $4 \mathrm{bc}$ is the only derivative that binds to residues on both sides of the ligandbinding site. 
Table $2 \mathrm{IC}_{50}$ and maximum non-cytotoxic concentration to normal cells established for the five pre-selected compounds (4 m, 4bt (dimethylenastron), 4p, 4bc and 4x) and monastrol

\begin{tabular}{|c|c|c|c|}
\hline \multirow[t]{2}{*}{ Compound } & \multicolumn{2}{|c|}{$\mathrm{I} C_{50}(\mu \mathrm{M})$} & \multirow{2}{*}{$\begin{array}{l}\text { Maximum non-cytotoxic } \\
\text { concentration to normal } \\
\text { cells }(\mathrm{mM})\end{array}$} \\
\hline & MCF-7 & MDA-MB-231 & \\
\hline $4 \mathrm{~m}$ & 197.3 & 77.08 & 1.0 \\
\hline $4 \mathrm{bt}$ & 126.9 & 17.91 & 0.8 \\
\hline $4 p$ & 87.5 & 68.38 & 0.4 \\
\hline $4 b c$ & 234.9 & 249.5 & 1.0 \\
\hline $4 x$ & 276.5 & 237.4 & 0.8 \\
\hline Monastrol & 110.4 & 113.9 & 1.0 \\
\hline
\end{tabular}

These concentrations were determined based on cells treatment for $72 \mathrm{~h}$.

Dimethylenastron (4bt) also exhibits an interesting interaction with Arg119. This interaction occurs both directly and by water-mediated means, which ensures a strong linkage between the compound and the residue. Arg119 also interacts with monastrol and 4bc, highlighting its importance during formation of the Eg5 protein ligand-binding site (Figure 3).

Derivatives $4 \mathrm{~m}$ and $4 \mathrm{x}$ interact with the Leu214 residue, but only $4 \mathrm{~m}$ interacts with Arg221. All of these direct interactions involve residues located at this $\alpha$-helix, without interacting with residues located at the other side of the site.

Conversely, $4 \mathrm{p}$ does not directly interact with any residue, showing only one water-mediated link to Gly117, which shows that the related $\alpha$-helix is of fundamental importance in the Eg5 catalytic site formation.

\section{Principal component and RMSD analysis}

Principal component analysis is a useful tool when the interest is searching for different motion modes during simulations [37]. This analysis was performed to confirm the influence of the first component during the simulation and to clarify the compounds interference on protein stability.

A comparison of the trajectories (Figure 4A) shows that $4 \mathrm{bc}$ leads the protein to a minor movement during the simulation. The $4 \mathrm{bc}$ derivative restricts protein movement in such a way that the first principal component gets close to zero in about 20 ns and remains (Figure 4A). Derivatives $4 \mathrm{~m}$ and $4 \mathrm{x}$ act in a similar way, but it is possible to see that $4 \mathrm{~m}$ leads the protein movements to a stabilized plateau after $40 \mathrm{~ns}$, while $4 \mathrm{x}$ remains in an increasing behavior. Dimethylenastron (4bt), $4 \mathrm{p}$ and monastrol are in the smallest ranges of all projections, but have a final projection value further from zero than $4 \mathrm{bc}$.

RMSD was also assessed to verify how different the structure becomes from the initial structural conformation during the simulation. It was noticeable that the compounds exerted influences of different magnitudes (Figure 4B): 4bc allowed an important initial shift in the protein conformation of approximately 0.5 to $20 \mathrm{~ns}$, and then the structure stabilized; $4 \mathrm{~m}$ exerted a significant influence on the structure until approximately $10 \mathrm{~ns}$, leading the protein to a shift of almost $0.4 \mathrm{~nm} ; 4 \mathrm{x}, 4 \mathrm{bt}$ (dimethylenastron) and monastrol displayed a similar influence on protein changes, leading the RMSD to a plateau of approximately $0.35 \mathrm{~nm}$; and $4 \mathrm{p}$ showed the least important influence, leading the structure to a plateau of $0.3 \mathrm{~nm}$ (Figure 4B).

\section{Kinesin Eg5 activity is inhibited in vitro by DHPM derivatives} Inhibition of kinesin Eg5 motor action by DHPMs was assessed in vitro. Compounds $4 \mathrm{bc}$ and $4 \mathrm{~m}$ inhibited Eg5 activity in a more pronounced way and were also more effective than monastrol. $4 \mathrm{~m}$ and $4 \mathrm{bc}$ reduced the maximum reaction rate $\left(\mathrm{V}_{\max }\right)$ from 18.67 to 16.52 and 15.30, respectively (data not shown). Compounds $4 \mathrm{bt}$

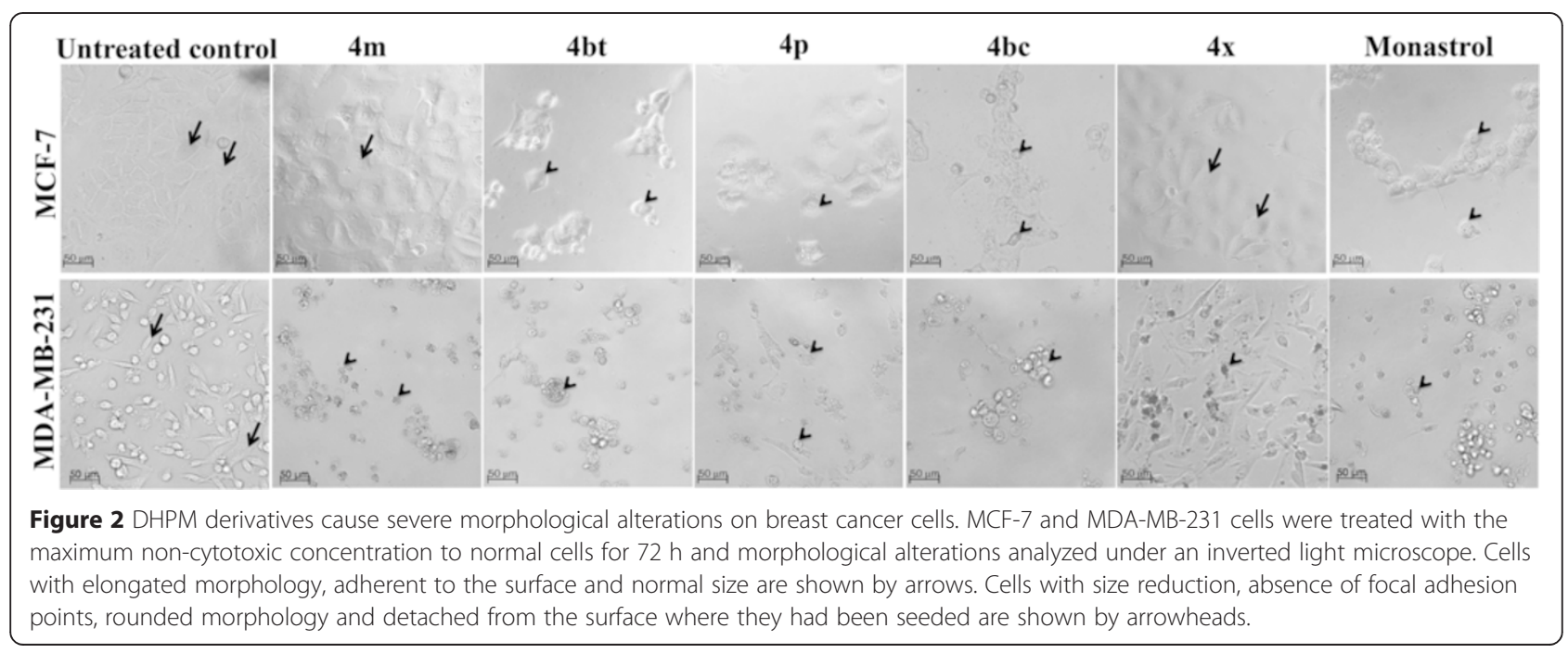



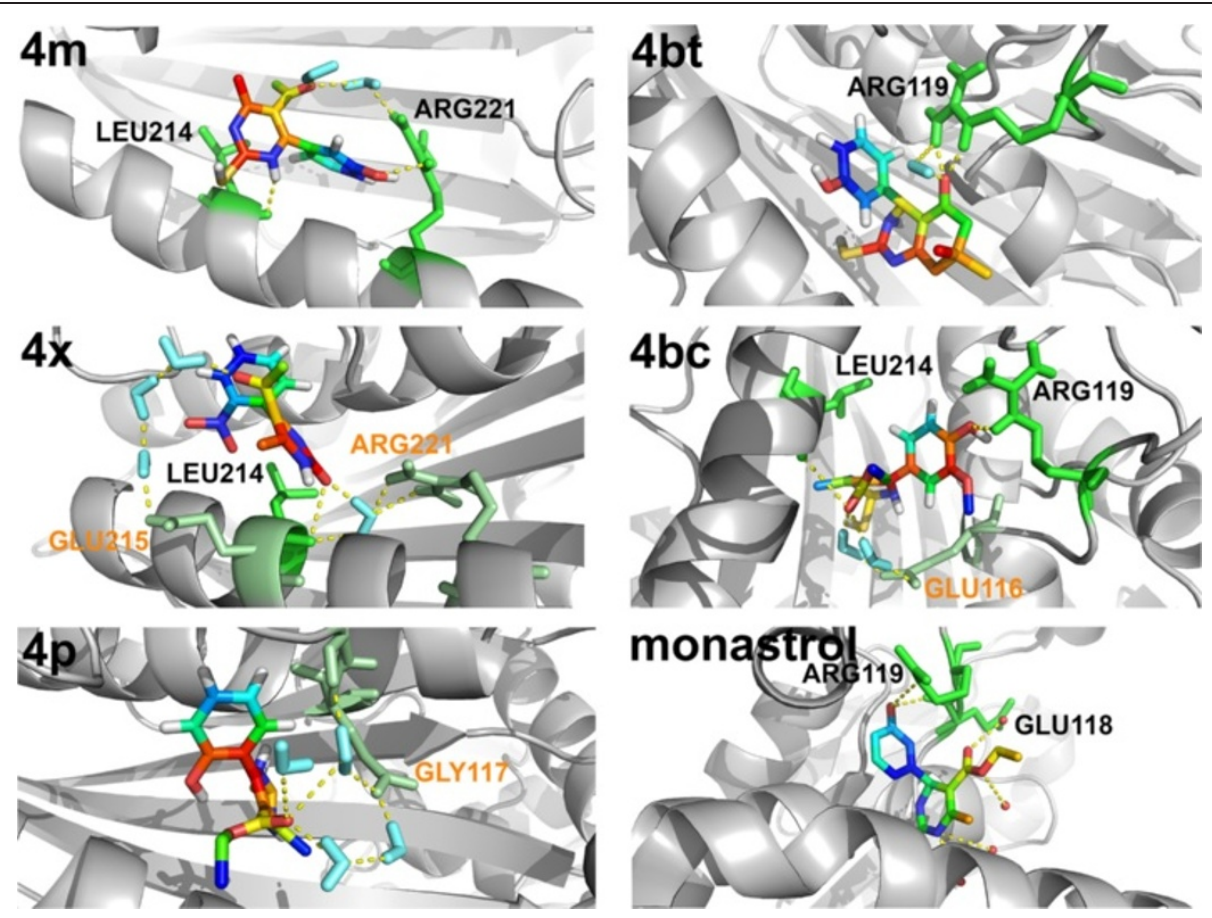

Figure 3 3D structure-based models of the Eg5 complexes after the MD assays. Molecular dynamics simulations (MD) of the Eg5 protein and Eg5 protein complexes with each of the five tested compounds were conducted to assess the DHMPs influence on Eg5 movements. The panels show ribbon representations of the Eg5 and Licorice representations of the tested compounds and monastrol. The yellow dotted lines show the polar contacts responsible for the maintenance of molecule linkage with the protein binding-site. The binding-region is perfectly conserved, but not the binding-residues, which lead us to realize the influence of the compound topology. Major differences may be seen in the interactions between $4 \mathrm{~m}, 4 \mathrm{x}$ and $4 \mathrm{p}$ and the Eg5 binding-site, which show completely different binding-residues. However, $4 \mathrm{bt}$ and $4 \mathrm{bc}$ retain the linkage with the Arg119 of the Eg5 when comparing to the monastrol, showing its importance in the inhibition processes. Indirect links mediated by water molecules (cyan), occur in residues (green) annotated in orange; direct links occur with residues annotated in black.

(dimethylenastron), 4p and 4x inhibited kinesin Eg5 in a similar way to monastrol however, this inhibitory activity was not statistically significant (Figure 4C).

\section{DHPMs treatment induces monoastral spindle formation and can lead human breast cancer cells to a mitotic catastrophe phenotype}

In order to verify the DHPMs interference with microtubule organization and mitotic spindle formation, immunofluorescence was performed using anti- $\alpha$-tubulin antibody. Four of the five tested compounds $(4 \mathrm{~m}$, dimethylenastron (4bt), $4 \mathrm{bc}$ and $4 \mathrm{x}$ ) caused monoastral spindle formation in MCF-7 cells during mitosis (Figure 5A), similar to monastrol, as previously reported [38]. These data corroborate our results obtained from the in vitro Kinesin inhibition assay, indicating that these compounds are indeed effective inhibitors of this protein activity. The percentage of cells with monoastral spindles that accumulate in asynchronous populations of MCF-7 cells treated for $24 \mathrm{~h}$ and $48 \mathrm{~h}$ is shown in Additional file 3: Table S1.

Treatment of MCF-7 cells with 4p (0.4 mM) produced a quite distinct pattern of microtubules organization, not observed for the other compounds/derivatives. Treated cells showed disruption of the microtubules, which were disordered and appeared to be concentrated in peripheral cell areas, adjacent to the plasmatic membrane (Figure 5A). Another observed change was the nuclear fragmentation phenotype with multiple micronuclei formation (Figure 5B), a common characteristic of a mitotic catastrophe.

In order to confirm that $4 \mathrm{p}$ treated cells undergo mitotic catastrophe, a supplementary transmission electron microscopy (TEM) analysis of these samples was performed. Treated cells showed nuclear fragmentation evidenced both by DAPI staining and TEM (Figure 5B). Plasma membrane integrity and a perinuclear vacuolization (Figure $5 \mathrm{~B}$ ) were also observed in a small number of cells from this sample. These observations strongly indicate that $4 \mathrm{p}$ treatment leads cells to a mitotic catastrophe phenotype [39].

\section{DHPMs-induced cell death occurs mainly by apoptosis}

We subsequently determined the type of cell death induced by DHPM derivatives in breast cancer cells. The majority of cells from both cell lines died by apoptosis 


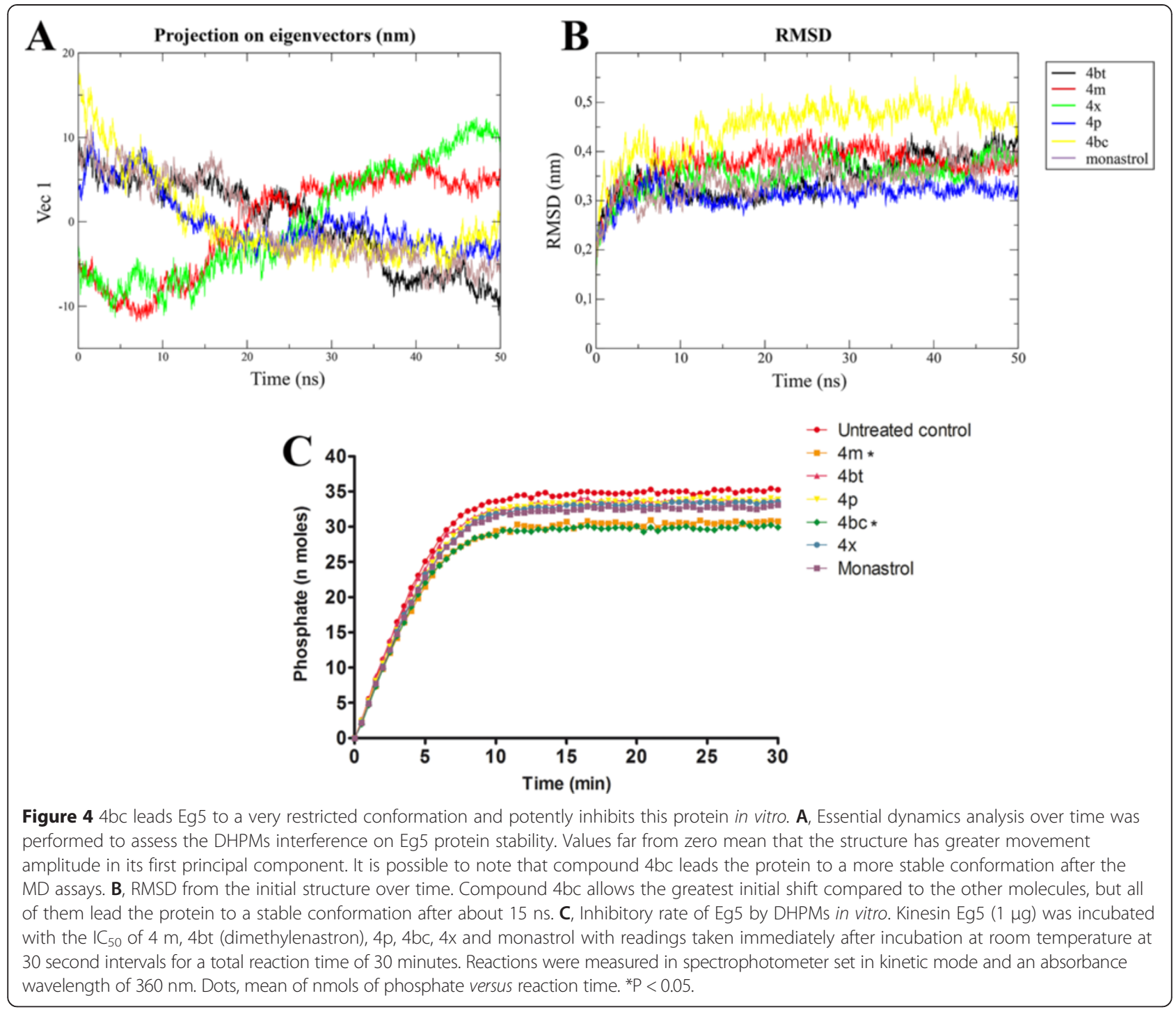

induced by treatment with the derivatives (Figure 6A). However, 4bc and 4bt (dimethylenastron) derivatives showed remarkable cell death induction, translated on antitumor activity. The $4 \mathrm{bc}$ derivative led to cell death by apoptosis: $92 \%$ and $97 \%$ of MCF-7 and MDA-MB231 cell populations, respectively. Dimethylenastron (4bt) induced apoptosis in 39\% and 83\% of cell populations in MCF-7 and MDA-MB-231, respectively; thus showing similar activity to that recorded for monastrol (Figure 6A). The other compounds ( $4 \mathrm{~m}, 4 \mathrm{p}$ and $4 \mathrm{x})$ also caused cell death by apoptosis, although a less pronounced manner.

These results indicate that treatment with DHPMs can foster a significant decrease in cell viability. Interestingly, the MDA-MB-231 cells are more susceptible to cell death induction by DHPM derivatives than MCF-7 cells. Minor doses and shorter treatment periods were sufficient to induce a high number of MDA-MB-231 cells to death (Figure 1A and $\mathrm{C}$ ). Therefore, a large number of dead cells were found with a late apoptosis profile after $72 \mathrm{~h}$ of treatment and not in early apoptosis as for MCF-7 cells (Figure 6A).

\section{DHPM derivatives potently repress breast tumor cell proliferation}

Proliferation is a crucial process in the maintenance and progression of cancer cells. Therefore, we monitored the effects of DHPM derivatives on proliferation of breast cancer cells, MCF-7 and MDA-MB-231, by using a CFSE assay followed by flow cytometry analysis after 72 hours of treatment.

Significant inhibition of the proliferation pattern was shown by the samples treated with $4 \mathrm{~m}$, 4bt (dimethylenastron), and 4p both in MCF-7 and in MDA-MB-231 cells, as was also observed for monastrol treatment. Approximately $50 \%$ of cell proliferation was inhibited after treatment with 


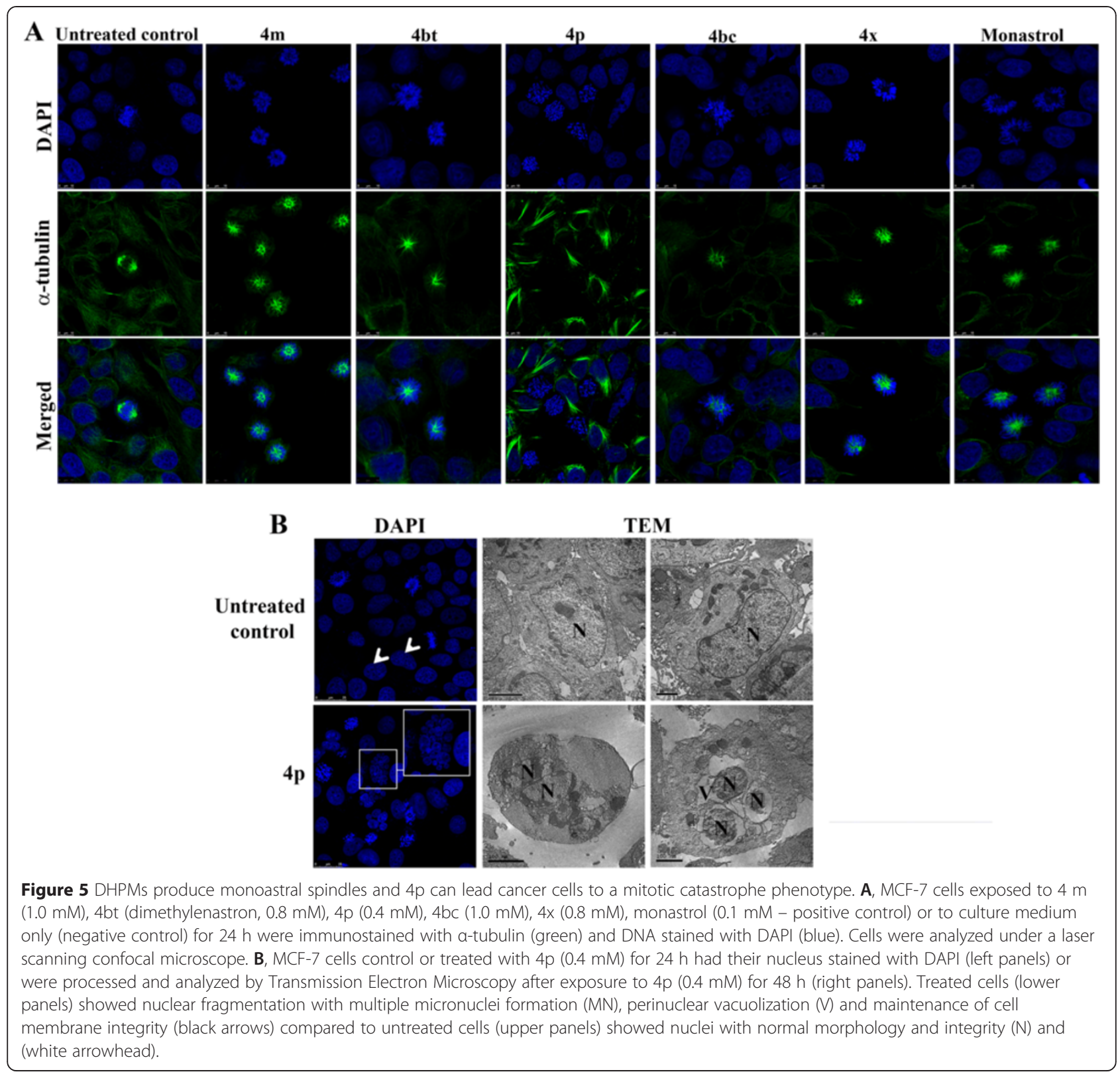

these derivatives (Figure 6B). Derivative 4bc also showed antiproliferative activity, but at a lower level.

\section{Treatment with some DHPMs may result in cell cycle arrest in G2/M phase}

In order to evaluate if DHPMs could impair normal cell cycle progression, the influence of the compounds on MCF-7 and MDA-MB-231 cells treated for 24, 48 and $72 \mathrm{~h}$ were analyzed. Our results demonstrated that after $48 \mathrm{~h}$ treatment, compounds $4 \mathrm{~m}, 4 \mathrm{p}$ and $4 \mathrm{x}$ caused a cell cycle arrest at G2/M in MCF-7 cells. The derivatives with high cytotoxic activity, 4bt (dimethylenastron) and $4 \mathrm{bc}$, led to a decrease of cells in $\mathrm{G} 2 / \mathrm{M}$ and an increase of cells in $\mathrm{S}$ phase (Figure 6C, left panel). Regarding MDA-MB-231 cells, only the $4 \mathrm{~m}$ derivative was able to cause cell arrest in G2/M. When considered in conjunction, these results indicate that this arrest in G2/M could not be observed in the treatments with more cytotoxic compounds because of the rapid cell elimination. No other significant change was observed in any stage of the cell cycle compared to the untreated control (Figure 6C, right panel). Results after $24 \mathrm{~h}$ and $72 \mathrm{~h}$ of treatment were less significant. Only the $4 \mathrm{~m}$ caused cell cycle arrest in G2/M in MCF-7 cells after 24 and $72 \mathrm{~h}$ of treatment and no alterations occurred in MDA-MB231 treated cells in these times (Additional file 4: Figure S2). 


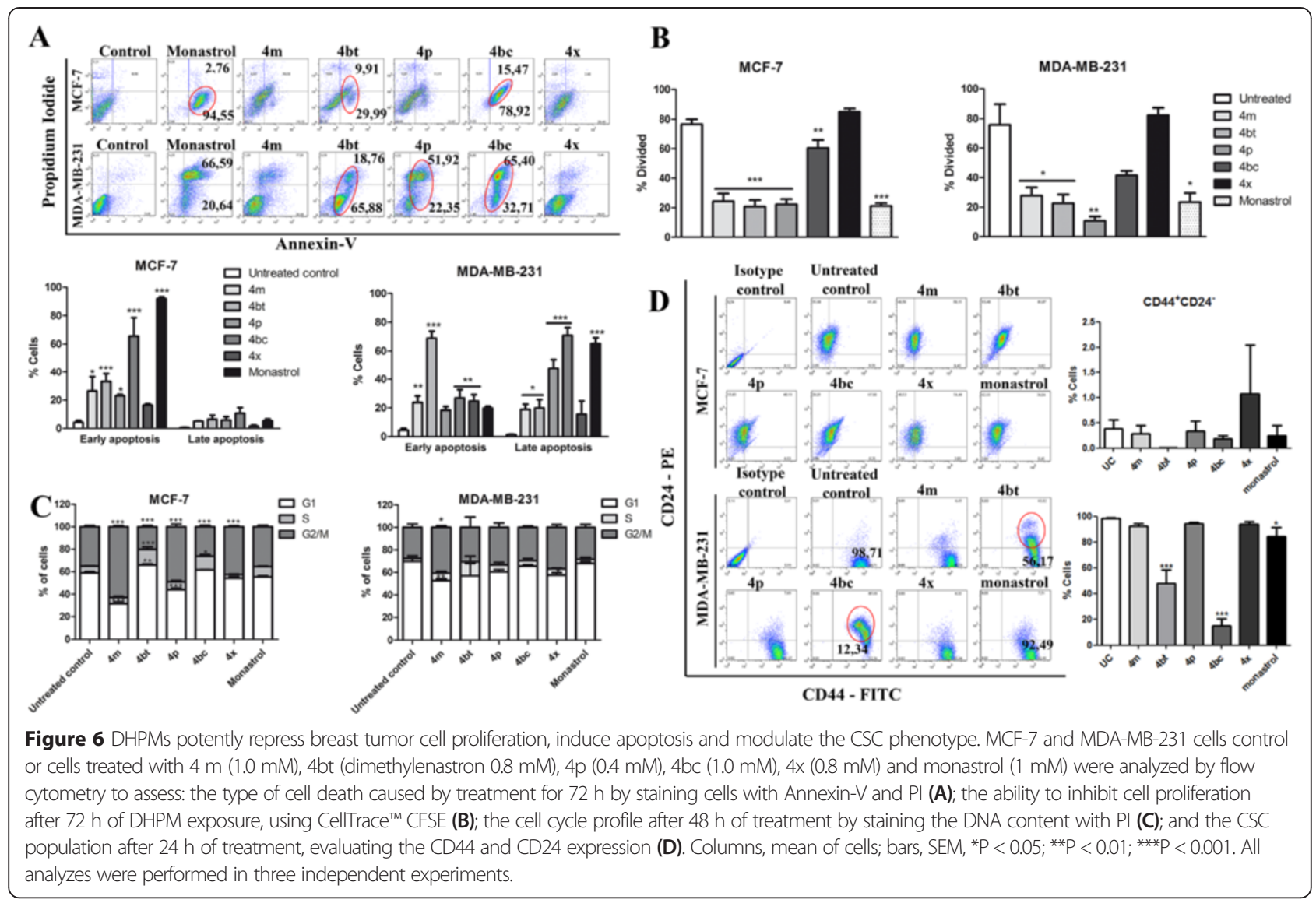

DHPMs lead to a decrease in the breast CSC subpopulation In breast cancer, a subset of markers, including: CD44 $4^{\text {hi }}$ CD24 ${ }^{\text {lo }}$, aldehyde dehydrogenase, Hoechst dye efflux, and the retention of the PKH26 lipophilic dye, have been shown to enrich CSC in various cell lines [40-42]. To investigate whether the DHPMs could influence the phenotypic profile on breast cancer cell subpopulations, CD44 and CD24 surface markers were evaluated in MCF-7 and MDA-MB-231 cells treated with each of the five derivatives.

The MCF-7 cells have a very small population of cancer stem cells with an average of $0.38 \%$ for $\mathrm{CD} 44^{+} / \mathrm{CD} 24^{-}$ cells. The treatment with DHPM has no impact on the expression of these markers and therefore does not change the amount of CSC in the MCF-7 cell population (Figure 6D and Additional file 5: Table S2). However, the results were extremely interesting regarding the influence of DHPM in modulating the expression of these molecules in MDA-MB-231 cells. Derivatives 4bt (dimethylenastron) and $4 \mathrm{bc}$ significantly decreased the $\mathrm{CD} 44^{+} / \mathrm{CD} 24^{-}$subpopulation from $98.45 \%$ (untreated control) to approximately $47.83 \%$ and $14.84 \%$, respectively (Figure 6D and Additional file 6: Table S3). We also observed a significant increase in the $\mathrm{CD} 44^{+} / \mathrm{CD} 24^{+}$phenotype in samples treated with these derivatives. These results indicate that 4bt (dimethylenastron) and 4bc compounds might be inducing a transition of MDA-MB-231 cells to a more epithelial profile.

\section{DHPM derivatives inhibit angiogenesis both in vitro and in vivo}

The effects of DHPM treatment on tube formation were evaluated in vitro using HUVEC cells, and in vivo using a model on chorioallantoic membrane (CAM) of fertilized chicken eggs. The in vitro assay demonstrated that HUVEC cells were capable of building tubes by connecting to neighboring cells forming a rich meshwork of branching capillary-like tubules (Figure 7A). However, following DHPM treatment at different concentrations $\left(30 \mu \mathrm{M}, \mathrm{IC}_{50}\right.$ and $\left.300 \mu \mathrm{M}\right)$, the intercellular connection was abrogated and HUVEC cells failed to form tubes. It was observed at the higher concentration that the capillary-like tubes were interrupted and most cells presented spherical morphology, either in isolation or aggregated in small clumps (Figure 7A). In addition, all the compounds resulted in a significant decrease in HUVEC tube formation mainly at the higher concentration $(300 \mu \mathrm{M})$ as quantified by patter recognition (Figure 7A right panel). Derivatives $4 \mathrm{p}$ and $4 \mathrm{bt}$ (dimethylenastron) were associated with the more pronounced anti-angiogenic 


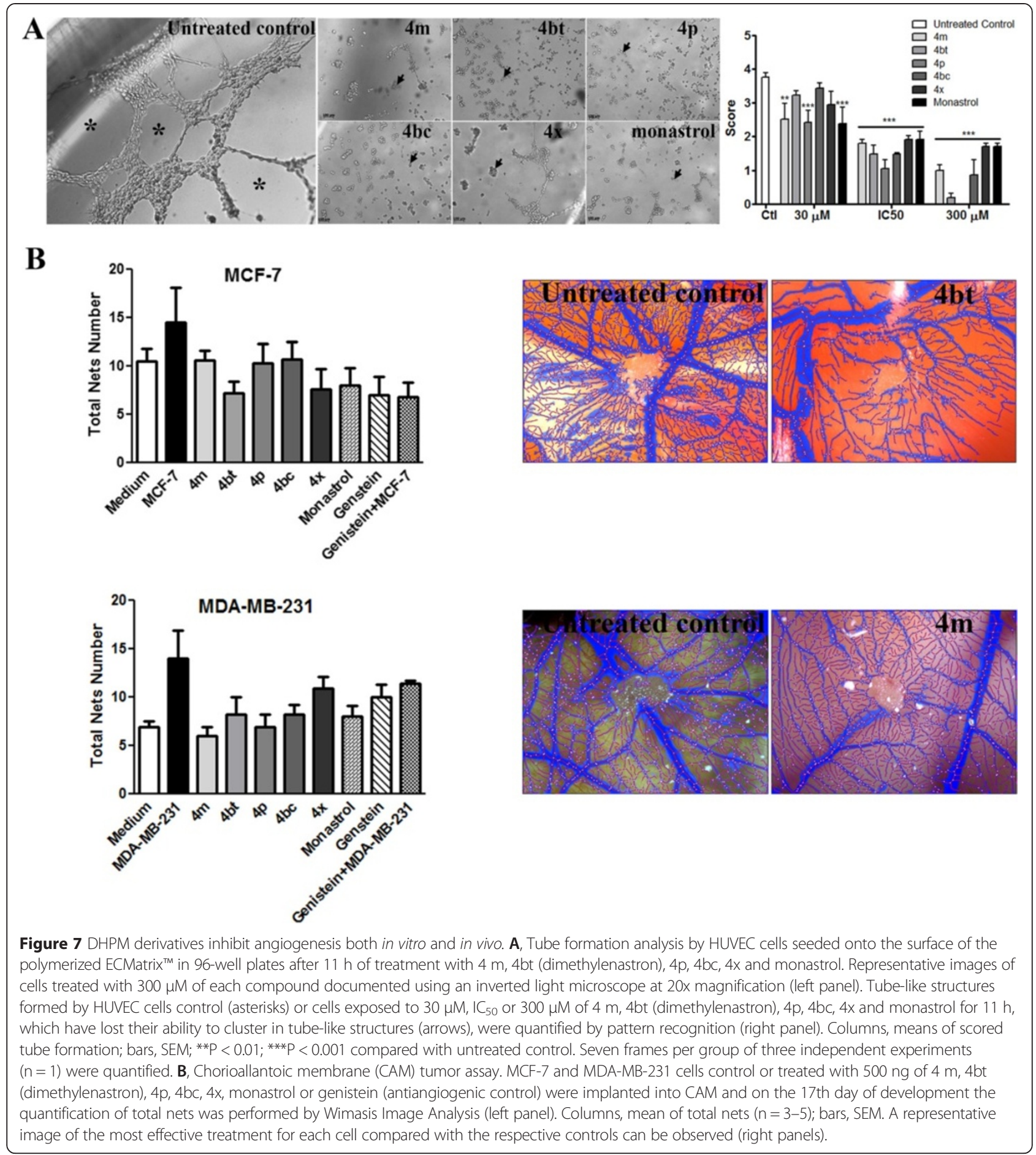

morphological aspect, which suggests that these derivative properties substantially interfered with the ability of HUVEC to form capillary-like structures in vitro.

To assess whether DHPM derivatives could also inhibit vessel formation by breast tumor cells, an in vivo model based on CAM of fertilized chicken eggs was performed. These results indicated that all derivatives were capable of subtly inhibiting new blood vessel formation at very low doses (500 ng) (Figure 7B). Although the anti-angiogenic properties presented by DHPM on the CAM assay were not statistically significant, our data suggests a marked reduction in vessel convergence toward tumor cell implantation and vessel thickness (Figure 7B - right 
panel). It is probable that the reduction in the total number of networks formed by vessels would be much more exacerbated at higher concentrations.

\section{Discussion}

In this study, we conducted an in vitro examination of the different aspects of cytotoxicity induced by 3,4-dihydropyrimidin-2(1H)-one (or thione) derivatives in MCF-7 and MDA-MB-231 cells. Several results suggest that DHPMs can inhibit kinesin Eg5 in a specific manner, leading to a critical error in mitotic spindle assembly, which in turn induces cell death by apoptosis. Apoptosis induction of cancer cells is the most pursued goal in drug development, as recently reviewed [43], due to its natural clearance effect, no association with inflammatory mechanisms, and its related role in tissue regeneration [44].

Cell proliferation is a crucial process relating to cancer initiation, maintenance and progression [45]. In our studies, cell treatments with low concentrations of $4 \mathrm{~m}$, $4 \mathrm{bt}$ (dimethylenastron), and $4 \mathrm{p}$ derivatives act primarily by preventing cell proliferation in both cell lines. These data suggest a very interesting DHPM cytostatic effect which is a useful property in targeting cancer cells that are resistant to apoptosis induction and have a poor response to proapoptotic agents.

Another very interesting finding was that at much lower concentrations, compound $4 \mathrm{p}$ showed high cytotoxic activity on breast tumor cells, however this effect was also well pronounced on normal cells which is probably due to the fact that this compound binds to another target rather than the Eg5 motor protein. Despite its lack of direct interaction with kinesin Eg5, as demonstrated by $\mathrm{MD}$ analysis (Figure 3 ) and visualized by $\alpha$-tubulin immunostaining (Figure 5A), 4p was able to induce cell death by mitotic catastrophe (Figure $5 \mathrm{~B}$ ).

According to Vitale and coworkers (2011), failing mitoses are often associated with chromosomal breakages and deficient karyokinesis, which lead to gross nuclear alterations (micronucleation and multinucleation) that constitute the most prominent morphological traits of mitotic catastrophe $[46,47]$. In addition, other typical features of this event are mitosis blockage, mitotic spindle disorganization and chromosome segregation failure [41]. Due to the activation of several death pathways following mitotic catastrophe, the induction of this event is considered a valid mechanism to subvert drug resistance [48]. It was also shown that molecules such as monastrol, dimethylenastron (4bt), K858 and ARRY-520 are able to trigger mitotic catastrophe and cell death by inhibiting kinesin $[11,49,50]$.

Our results indicated $4 \mathrm{bc}$ as a potent and specific antitumor agent. This molecule showed dose-dependent lethal action against tumor cells, but not for normal cells, and together with $4 \mathrm{bt}$ (dimethylenastron) is considered the most promising of the compounds tested. These results corroborate molecular dynamics data, in which reveals these compounds form more stable bonds with Eg5 protein residues, and these connections are made in the common residues that monastrol binds to [51]. The binding-site sealing, promoted by the linkage of $4 \mathrm{bc}$, prominently inhibit protein mobility, causing a significant reduction of its major mobility-dependent functions. The MD results show that this mechanism of action can be the main cause of Eg5 inhibition by $4 \mathrm{bc}$. Since the other compounds did not show a relevant stiffening promotion, as observed for $4 \mathrm{bc}$, it is possible to assume that there is a strong relationship between protein movements and its activity. Furthermore, it is possible to understand the importance of Arg119 in catalytic binding-site formation, since the majority of inhibitory molecules interact with this residue. Reviewing the essential dynamics and RMSD results; it is easy to see that $4 \mathrm{bc}$ leads Eg5 structure to an interesting shift, and ultimately to an important stabilization, different from the other compounds. This stabilization in a different structural conformation may be the key to the competitive inhibition of Eg5 activity.

In addition to these properties, $4 \mathrm{bc}$ and $4 \mathrm{bt}$ (dimethylenastron) also affect a very important property of tumor establishment and maintenance - the presence of cancer stem cells. CSC are defined by their tumor-initiating properties which appear to be responsible for driving tumor growth, recurrence, and metastasis [40,52]. We detected a considerable decrease in CSC population $\left(\mathrm{CD} 44^{+} / \mathrm{CD} 24^{-}\right)$ in MDA-MB-231 cells treated with $4 \mathrm{bc}$ and $4 \mathrm{bt}$ (dimethylenastron) and an increase in the $\mathrm{CD} 44^{+} / \mathrm{CD} 24^{+}$population. This was a surprising result in that it was previously verified that CSC isolated from breast cancer cell lines are resistant to radiation and chemotherapy [53,54]. Furthermore, these treatments can select for the outgrowth of therapy-resistant cancer cell subpopulations that are more tumorigenic, invasive, and stem like [55,56]. Hence, cancer therapies may be rendered ineffective because the bulk of cancer cells within a tumor may be eliminated while leaving slow cycling cells behind, such as CSC which are also resistant to apoptosis and proceed to regenerate the tumor [57-59]. This alteration in cells that become more epithelial $\left(\mathrm{CD} 44^{+} / \mathrm{CD} 24^{+}\right)[60]$ allowed them to acquire susceptibility to cytotoxic effects produced by DHPMs or other anticancer agents. Further studies are necessary in order to characterize the molecular aspects related with CSC under DHPMs derivatives treatment.

\section{Conclusions}

Our results provide evidence of potent Eg5 inhibitors, the DHPMs derivatives, which prevent normal mitotic spindle formation during cell division inducing breast tumor cells to apoptosis, besides to show that several cellular processes are impaired by DHPMs activity differently 
of many works that show only viability data just from tumoral cells. Thus, the major overall findings obtained from the analyses are:

i) DHPM derivatives are potent Eg5 inhibitors and have potent activity against MCF-7 and MDA-MB-231 cells with low cytotoxicity to normal cells affording a great advantage over current drugs widely used in cancer treatment;

ii) Two compounds (4bt and $4 \mathrm{bc}$ ) are more efficient than monastrol, a widely recognized inhibitor of Eg5 activity;

iii) The DHPMs are able to interfere, in vitro, with the development of essential properties for tumor establishment and progression such as cell proliferation, angiogenesis, and CSC phenotype;

iv) The cytotoxic effect of DHMPs is accompanied by the induction of apoptosis in MCF-7 and MDA-MB-231 cells

v) DHPM architecture is a promising chemotherapeutic candidate because of its selective bioactivity in tumor cells, which should be further evaluated by in vivo assays.

\section{Additional files}

Additional file 1: Supplementary Methods - A detailed methodology about material, equipment and molecular dynamics).

Additional file 2: Figure S1. Effects of DHPM derivatives on MCF-7 and MDA-MB-231 cell viability.

Additional file 3: Table S1. Quantification of monopolar spindles occurred as a result of treatment of MCF-7 cells with DHPM derivatives.

Additional file 4: Figure S2. Effects of DHPM derivatives on MCF-7 and MDA-MB-231 cell cycle profile after 24 and $72 \mathrm{~h}$ of treatment.

Additional file 5: Table S2. Percentage of subpopulations defined by the combination of stem cell markers CD44 and CD24 in MCF-7 cells.

Additional file 6: Table S3. Percentage of subpopulations defined by the combination of stem cell markers CD44 and CD24 in MDA-MB-231 cells.

\section{Abbreviations}

BSA: Bovine serum albumin; CAM: Chorioallantoic membrane; CFSE: 5-(and 6-)-carboxyfluorescein diacetate succinimidyl ester; CSC: Cancer stem cell; DHPMs: 3,4-dihydropyrimidin-2(1H)-one (or thione); ELIPA: Enzyme linked inorganic phosphate assay; FBS: Fetal bovine serum; HUVEC: Human umbilical vein endothelial cell; MCF-7: Michigan Cancer Foundation 7 breast cancer cell line; MD: Molecular dynamics; MDAMB231: Breast cancer cell line derived from metastatic site (pleural effusion); MTT: 3-(4,5-dimethylthiazol-2-yl)2,5-diphenylterazolium bromide; PDB: Protein data bank; SAC: Spindle assembly checkpoint; SPC: Single point charge; RMSD: Root-mean-square deviation; TEM: Transmission electron microscope.

\section{Competing interests}

No potential conflicts of interest have been disclosed.

\section{Authors' contributions}

Conception and design: JRC, BCG Development of methodology: JRC, BC, LMR, DON, CCN, BYGA, AP, BADN Acquisition of data (provided animals, acquired and managed patients, provided facilities, etc.): JRC, BCG, LMR, DON, CCN, BYGA, BADN Analysis and interpretation of data (e.g., statistical analysis, biostatistics, computational analysis): BCG, JRC, DON, CCN, BYGA Writing, review, and/or revision of the manuscript: BCG, JRC, DON, AP, BADN, Administrative, technical, or material support (i.e., reporting or organizing data, constructing databases): JRC, Study supervision: JRC, BADN Provision of compounds designed to inhibit Kinesin Eg-5 for use in the experiments: $B A D N, L M R$. All authors read and approved the final manuscript.

\section{Acknowledgments}

The Molecular Dynamics research was supported by resources supplied by the Center for Scientific Computing (NCC/GridUNESP) of the São Paulo State University (UNESP). INCT-Catalysis, FINATEC, FAPDF, Fundação Universidade de Brasília, CAPES and CNPq are acknowledged for their partial financial support.

\section{Author details}

Department of Cell Biology, Laboratory of Electron Microscopy, University of Brasília (IB-UnB), Campus Universitário Darcy Ribeiro, Brasília, DF, Brazil. ${ }^{2}$ Laboratory of Medicinal and Technological Chemistry, University of Brasília (IQ-UnB), Brasília, Distrito Federal, Brazil. ${ }^{3}$ Research Laboratory of Electronics, Massachusetts Institute of Technology (MIT), Cambridge, Massachusetts, USA. ${ }^{4}$ Physics Course, Catholic University of Brasília, Brasília, Distrito Federal, Brazil. ${ }^{5}$ Laboratory of Embryology and Developmental Biology, Genetics and Morphology Department, University of Brasília (IB-UnB), Brasília, Distrito Federal, Brazil.

Received: 20 November 2014 Accepted: 26 March 2015

Published online: 14 April 2015

\section{References}

1. Siegel R, Naishadham D, Jemal A. Cancer Statistics, 2012. CA Cancer J Clin. 2012;1:10-29.

2. Chacon-Cortes D, Smith RA, Lea RA, Youl PH, Griffiths LR. Association of microRNA 17-92 cluster host gene (MIR17HG) polymorphisms with breast cancer. Tumour Biol. 2015. in press.

3. Kapoor TM, Mitchison TJ. Eg5 is static in bipolar spindles relative to tubulin: evidence for a static spindle matrix. J Cell Biol. 2001;154:1125-33.

4. Yokoyama H, Sawada J-I, Katoh S, Matsuno K, Ogo N, Ishikawa Y, et al. Structural basis of new allosteric inhibition in Kinesin Spindle Protein Eg5. ACS Chem Biol. 2015. in press.

5. Yamamoto J, Amishiro N, Kato K, Ohta Y, Ino Y, Araki M, et al. Synthetic studies on mitotic kinesin Eg5 inhibitors: synthesis and structure-activity relationships of novel 2,4,5-substituted-1,3,4-thiadiazoline derivatives. Bioorg Med Chem Lett. 2014;24:3961-3.

6. Debonis S, Skoufias DA, Lebeau L, Lopez R, Robin G, Margolis RL, et al. In vitro screening for inhibitors of the human mitotic kinesin Eg5 with antimitotic and antitumor activities. Cancer Res. 2004;3(9):1079-90.

7. El-Nassan HB. Advances in the discovery of kinesin spindle protein (Eg5) inhibitors as antitumor agents. Eur J Med Chem. 2013;62:614-31.

8. Weil D, Garçon L, Harper M, Duménil D, Dautry F, Kress M. Targeting the kinesin Eg5 to monitor siRNA transfection in mammalian cells. Biotechniques. 2002;33:1244-8.

9. Valentine MT, Gilbert SP. To step or not to step? How biochemistry and mechanics influence processivity in Kinesin and Eg5. Curr Opin Cell Biol. 2007;19(1):75-81.

10. Ishikawa K, Tamura Y, Maruta S. Photocontrol of mitotic kinesin Eg5 facilitated by thiol-reactive photochromic molecules incorporated into the loop L5 functional loop. J Biochem. 2014;155:195-206.

11. Mayer TU, Kapoor TM, Haggarty SJ, King RW, Schreiber SL, Mitchison TJ. Small molecule inhibitor of mitotic spindle bipolarity identified in a phenotype-based screen. Science. 1999;286:971-4.

12. Kapoor TM, Mayer TU, Coughlin ML, Mitchison TJ. Probing Spindle Assembly Mechanisms with Monastrol, a Small Molecule Inhibitor of the Mitotic Kinesin, Eg5 7. Assembly. 2000;150:975-88

13. Stern BM, Murray AW. Lack of tension at kinetochores activates the spindle checkpoint in budding yeast. Curr Biol. 2001;11:1462-7.

14. Nguyen DX, Bos PD, Massagué J. Metastasis: from dissemination to organ- specific colonization. Nat Rev Cancer. 2009;9:274-84.

15. Friedl $P$, Alexander S. Review Cancer Invasion and the Microenvironment: Plasticity and Reciprocity. Cell. 2011;147:992-1009.

16. Martinez N, Boire A, Deangelis LM. Molecular interactions in the development of brain metastases. Int J Mol Sci. 2013;14:17157-67. 
17. Jaggupilli A, Elkord E. Significance of CD44 and CD24 as cancer stem cell markers: an enduring ambiguity. Clin Dev Immunol. 2012;2012:708036.

18. Arnold KM, Opdenaker LM, Flynn D, Sims-Mourtada J. Wound healing and cancer stem cells: inflammation as a driver of treatment resistance in breast cancer. Cancer Growth Metastasis. 2015;8:1-13.

19. Charafe-Jauffret E, Ginestier C, lovino F, Wicinski J, Cervera N, Finetti $P$, et al. Breast cancer cell lines contain functional cancer stem cells with metastatic capacity and a distinct molecular signature. Cancer Res. 2009;69(4):1302-13.

20. Jordan CT, Guzman ML, Noble M. Cancer stem cells. N Engl J Med. 2006;355:1253-61.

21. Bauerschmitz GJ, Ranki T, Kangasniemi L, Ribacka C, Eriksson M, Porten M, et al. Tissue-specific promoters active in CD44 + CD24-/low breast cancer cells. Cancer Res. 2008;68:5533-9.

22. Sun X, Shi X, Sun X, Luo Y, Wu X, Yao C, et al. Dimethylenastron suppresses human pancreatic cancer cell migration and invasion in vitro via allosteric inhibition of mitotic kinesin Eg5. Acta Pharmacol Sin. 2011;32:1543-8.

23. Kamal A, Malik MS, Bajee S, Azeeza S, Faazil S, Ramakrishna S, et al. European Journal of Medicinal Chemistry Synthesis and biological evaluation of conformationally flexible as well as restricted dimers of monastrol and related dihydropyrimidones. Eur J Med Chem. 2011;46:3274-81

24. Canto RFS, Bernardi A, Battastini AMO, Russowsky D, Eifler-Lima VL. Synthesis of dihydropyrimidin-2-one/thione library and cytotoxic activity against the human U138-MG and Rat C6 glioma cell lines. J Braz Chem Soc 2011;22:1379-88.

25. Figueiró F, Mendes FB, Corbelini PF, Janarelli F, Helena E, Jandrey F, et al. A monastrol-derived compound, LaSOM 63 , inhibits ecto-5' nucleotidase/CD73 activity and induces apoptotic cell death of glioma cell lines. Anticancer Res. 2014;1842:1837-42.

26. Sośnicki JG, Struk Ł, Kurzawski M, Perużyńska M, Maciejewska G, Droździk M. Regioselective synthesis of novel 4,5-diaryl functionalized 3,4dihydropyrimidine- $2(1 \mathrm{H})$-thiones via a non-Biginelli-type approach and evaluation of their in vitro anticancer activity. Org Biomol Chem. 2014;12:3427-40.

27. Müller C, Gross D, Sarli V, Gartner M, Giannis A, Bernhardt G, et al. Inhibitors of kinesin Eg5: Antiproliferative activity of monastrol analogues against human glioblastoma cells. Cancer Chemother Pharmacol. 2007;59:157-64.

28. Wood KW, Cornwell WD, Jackson JR. Past and future of the mitotic spindle as an oncology target. Curr Opin Pharmacol. 2001;1:370-7.

29. Malik B, Stillman M. Chemotherapy-induced peripheral neuropathy. Curr Pain Headache Rep 2008:165-174.

30. Russowsky D, Canto RFS, Sanches SA, D'Oca MG, de Fátima A, Pilli RA, et al. Synthesis and differential antiproliferative activity of Biginelli compounds against cancer cell lines: monastrol, oxo-monastrol and oxygenated analogues. Bioorg Chem. 2006;34:173-82.

31. Ramos LM, Guido BC, Nobrega CC, Corrêa JR, Silva RG, de Oliveira HCB, et al. The Biginelli reaction with an imidazolium-tagged recyclable iron catalyst: kinetics, mechanism, and antitumoral activity. Chemistry. 2013;19:4156-68.

32. Berendsen HJC, Postma JPM, Van Gunsteren WF, Hermans J. Interaction models for water in relation to protein hydration. Intermol Forces. 1981;11 Suppl 1:331-8.

33. Hess B, Kutzner C, Van Der Spoel D, Lindahl E. GROMACS 4: Algorithms for Highly Efficient, Load-Balanced, and Scalable Molecular Simulation. J Chem Theory Comput. 2008;4:435-47.

34. Ribatti D. Chicken Chorioallantoic Membrane Angiogenesis Model. In: Cardiovascular Development: Methods and Protocols, Methods in Molecular Biology - Chapter 5. Volume 843. Heidelberg,DE: Humana Press; 2012. p. 47-57.

35. Sun H, Jia J, Wang X, Ma B, Di L, Song G, et al. CD44+/CD24- breast cancer cells isolated from MCF-7 cultures exhibit enhanced angiogenic properties. Clin Transl Oncol. 2012;15:46-54.

36. Miki H, Okada Y, Hirokawa N. Analysis of the kinesin superfamily: insights into structure and function. Trends Cell Biol. 2005;15:467-76.

37. Amadei A, Linssen AB, Berendsen HJ. Essential dynamics of proteins. Proteins. 1993;17:412-25.

38. Hsu L, Durrant DE, Huang C, Chi N, Baruchello R, Rondanin R, et al. Development of hemiasterlin derivatives as potential anticancer agents that inhibit tubulin polymerization and synergize with a stilbene tubulin inhibitor. Drugs. 2011;4:1379-88.
39. Castedo M, Perfettini J-L, Roumier T, Andreau K, Medema R, Kroemer G. Cell death by mitotic catastrophe: a molecular definition. Oncogene. 2004;23:2825-37.

40. Al-Hajj M, Wicha MS, Benito-Hernandez A, Morrison SJ, Clarke MF. Prospective identification of tumorigenic breast cancer cells. Proc Natl Acad Sci U S A. 2003;100:3983-8

41. Ginestier C, Hur MH, Charafe-Jauffret E, Monville F, Dutcher J, Brown M, et al. ALDH1 is a marker of normal and malignant human mammary stem cells and a predictor of poor clinical outcome. Cell Stem Cell. 2007;1:555-67.

42. Pece S, Tosoni D, Confalonieri S, Mazzarol G, Vecchi M, Ronzoni S, et al. Biological and molecular heterogeneity of breast cancers correlates with their cancer stem cell content. Cell. 2010;140:62-73.

43. Cerella C, Teiten M-H, Radogna F, Dicato M, Diederich M. From nature to bedside: pro-survival and cell death mechanisms as therapeutic targets in cancer treatment. Biotechnol Adv. 2014;32(6):1111-22.

44. Vriz S, Reiter S, Galliot B. Cell death: a program to regenerate. Curr Top Dev Biol. 2014;108:121-51.

45. Barrett JC. Mechanisms of multistep carcinogenesis and carcinogen risk assessment. Environ Health Perspect. 1993;100:9-20.

46. Kroemer G, Galluzzi L, Vandenabeele P, Abrams J, Alnemri ES, Baehrecke EH, et al. Classification of cell death: recommendations of the Nomenclature Committee on Cell Death 2009. Cell Death Differ. 2009;16:3-11.

47. Vitale I, Galluzzi L, Castedo M, Kroemer G. Mitotic catastrophe: a mechanism for avoiding genomic instability. Nat Rev Mol Cell Biol. 2011;12:385-92.

48. Wolanin K, Magalska A, Mosieniak G, Klinger R, McKenna S, Vejda S, et al. Curcumin affects components of the chromosomal passenger complex and induces mitotic catastrophe in apoptosis-resistant Bcr-Abl-expressing cells. Mol Cancer Res. 2006;:457-69.

49. Rello-varona S, Vitale I, Kepp O, Senovilla L, Jemaá M, Métivier D, et al. Preferential killing of tetraploid tumor cells by targeting the mitotic kinesin Eg5. Cell Cycle. 2009;7:1030-5.

50. Carter BZ, Mak DH, Woessner R, Gross S, Schober WD, Estrov Z, et al. Inhibition of KSP by ARRY-520 induces cell cycle block and cell death via the mitochondrial pathway in AML cells. Leukemia. 2009;23:1755-62.

51. Tcherniuk S, Van Lis R, Kozielski F, Skoufias DA. Mutations in the human kinesin $\mathrm{Eg} 5$ that confer resistance to monastrol and S-trityl- $\mathrm{L}$-cysteine in tumor derived cell lines. Biochem Pharmacol. 2010;79:864-72.

52. Dalerba P, Cho RW, Clarke MF. Cancer stem cells: models and concepts. Annu Rev Med. 2007:58:267-84.

53. Chiotaki R, Polioudaki H, Theodoropoulos PA. Cancer stem cells in solid and liquid tissues of breast cancer patients: characterization and therapeutic perspectives. Curr Cancer Drug Targets. 2015. in press.

54. Dawood S, Austin L, Cristofanilli M. Cancer stem cells: implications for cancer therapy. Oncology (Williston Park). 2014;28(12):1101-7.

55. Creighton CJ, Li X, Landis M, Dixon JM, Neumeister VM, Sjolund A, et al. Residual breast cancers after conventional therapy display mesenchymal as well as tumor-initiating features. Proc Natl Acad Sci U S A. 2009;106:13820-5.

56. Gupta PB, Onder TT, Jiang G, Tao K, Kuperwasser C, Weinberg RA, et al. Identification of selective inhibitors of cancer stem cells by high-throughput screening. Cell. 2009;138:645-59.

57. Reya T, Morrison SJ, Clarke MF, Weissman IL. Stem cells, cancer, and cancer stem cells. Nature. 2001;414:105-11.

58. Tam WL, Lu H, Buikhuisen J, Soh BS, Lim E, Reinhardt F, et al. Protein kinase $\mathrm{C} a$ is a central signaling node and therapeutic target for breast cancer stem cells. Cancer Cell. 2013;24:347-64.

59. Zhou B-BS, Zhang H, Damelin M, Geles KG, Grindley JC, Dirks PB, Tumour- initiating cells: challenges and opportunities for anticancer drug discovery. Nat Rev Drug Discov. 2009;8:806-23.

60. Ricardo S, Vieira AF, Gerhard R, Leitão D, Pinto R, Cameselle-Teijeiro JF, et al. Breast cancer stem cell markers CD44, CD24 and ALDH1: expression distribution within intrinsic molecular subtype. J Clin Pathol. 2011;64:937-46. 